to bear tax burdens. Some objections have been raised to the use of the principle, but most of them are weak and apply to some of the purposes for which it has been proposed rather than to the tax itself. Much litigation has arisen over its use, but the court decisions have generally strengthened the position of the principle as a part of fiscal systems.

In the use of the tax, many problems have arisen, particularly in the formulation of just laws, and in the double and multiple taxes which have been placed upon single estates because of conflicting jurisdictions. The tax has been used by the Federal Government at different times as an emergency measure, and may be continued as a part of its fiscal machinery. The states have used it more or less since 1826 but it is only in recent years that much importance has been attached to the fiscal possibilities. Foreign countries have developed comprehensive systems of inheritance taxes.

Since inheritance taxes so admirably supplement income taxes, and since each has become so deservedly popular among fiscal authorities and officials, it is not too much to expect that each will hold a place of vital importance in future revenue systems, not only of federal governments, but also of the provinces and states. Because of its backwardness in the past, the United States may be looked upon to furnish examples of the most rapid extension of the use of inheritance taxes during the next few decades.

\title{
The Net Income and Excess Profits Should Be Kept as the Main Sources of National Taxation
}

\author{
By H. C. McKenzie \\ Treasurer, The New York State Federation of County Farm Bureau Associations
}

$\mathrm{T}$ IIME was when the average citizen gave mighty little attention to the methods of raising the revenue necessary to run the government: almost all the revenue necessary was raised by the tariff and a tax on booze. Some time ago a great cry was raised because Congress spent a billion dollars in two years. It was called "The Billion Dollar Congress." It is a far cry from that time and an annual budget of $\$ 500,000,000$ to the fiscal year 1921 and a budget of $\$ 5,600,000,000$.

During the last six months there has been a determined effort to work up public sentiment in favor of changing some of the important features of our present tax laws, notably in favor of lowering the higher brackets of the surtaxes on individuals and in favor of the repeal of the excess profits tax on corporations. Part of this agitation has been an honest effort to determine how the necessary revenue should be raised, but a great deal of it has been propaganda put out by those who are now carrying a heavy tax burden, and who most earnestly desire to shift the burden to other shoulders. The papers and magazines have been full of statements that the taxes are ruining business, that the excess profits tax must be repealed, and that the system must be revised, and generally without any clear statement of what is to take the place of the abolished schedule. 


\section{Sources of Revenue}

The difference between the calendar year and the fiscal year of the government must be kept in mind; also that the fiscal year is known as of the year in which it ends. For example, the fiscal year ending last June 30th was the fiscal year 1920, and we are now in the fiscal year of 1921 and the taxes paid July and December are figured in that year. For the fiscal year 1921 the estimates are: bulk of the taxes should be levied and collected on that basis.

2. The tax should be progressive, that is, the greater the income, the higher the rate.

3. As this is the country of all the people, all the people should have some part in supporting the government, and a certain part of the revenues may justly be raised by means of the tariff and other consumption taxes.

4. While recognizing that the first

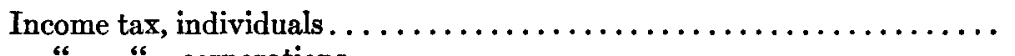

$\$ 1,310,000,000$

" corporations................................

Excess profits tax.........................................

Other internal revenue taxes....................................

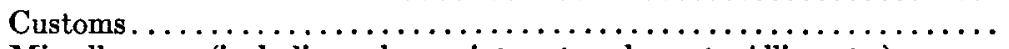

Miscellaneous (including salvage, interest on loans to Allies, etc.)........

Postal revenue (which approximate the appropriations for this purpose). . $550,000,000$

$1,300,000,000$

$1,350,000,000$ $360,000,000$ $651,000,000$ $462,575,190$

$\$ 5,983,575,190$

No revision can lessen the tax burdenit can only distribute it equitably; only retrenchment can lessen it.

If the present estimates are correct, the taxes now in force will produce enough revenue to carry on the government and wipe out $\$ 2,500,000,000$ of the floating debt by 1923 when refunding operations on a large scale will have to be undertaken. Financiers all agree that it is of the highest importance that this floating debt be not left to embarrass the refunding operations, so that the only hope for lowering taxes during the next three years lies in lowering expenses. The people of the country will cheerfully furnish the money that is necessary to run the government, but will raise a storm of protest against waste and extravagance.

Four general principles should be kept in mind in any discussion of this subject:

1. The measure of ability to pay taxes for the support of the National Government is net income, and the consideration in any scheme of taxation is the raising of revenue, its collateral effects must not be lost sight of and, in so far as practicable, the taxes should be so levied as to tend to the distribution of wealth in the hands of the many and not its concentration in the hands of the few.

These four principles are the standards by which to measure the various proposals for revision that are being considered at this time.

\section{Net Income Measures Ability to Pay}

Taxes can be paid only from two sources: Income and capital. So far as I know, there is no responsible body of public opinion in this country in favor of a levy on capital. The only country in the world that has resorted to that means of securing revenue today is Germany, and she has been driven to it as a last resort.

If then the bulk of the tax is to be derived from net income, it should be determined by reference to the amount of that income, not with reference to 
some other factor with no fixed relation to net income, as, for example, gross income. It might be asked: Why then is not all revenue raised by income taxes? The chief reason is that it is not practical to get income tax returns from the great mass of the people with low incomes. It would involve the making of thirty or forty million returns and the checking and handling of them would be out of the question at any reasonable cost.

The consumption taxes are the means adopted for collecting the tax from those of low incomes. They may be looked upon as the base tax spread over all the people; as incomes increase, ability to pay increases, and the income taxes in progressive form are intended to graduate the payments according to ability to pay.

The ideal consumption tax would be one on an article, not a necessity, of universal consumption, one that would carry the tax without shutting off its use. There is no such article, and so a number of articles have been selected that theoretically distribute the burden equitably.

\section{Progressive Taxation}

A man's ability to pay taxes increases faster than his income. If a man having an income of $\$ 10,000$ can justly be required to pay 10 per cent, or $\$ 1,000$, a man with an income of $\$ 100,000$ can pay more than 10 per cent. The rate should never be so high, however, as to take away from the individual the incentive to earn, or it will automatically defeat the object in view, as it has been abundantly proven that altruism is not a sufficient incentive to cause the human race to put forth its best efforts.

\section{How Revenues Should Be Raised}

The great problem to be settled by Congress is how much should be raised by income taxes and how much by consumption taxes. Approximately $5,600,000$ people made income tax returns in 1919 with an income of twenty billions. The income of corporations was about $\$ 8,900,000,000$. If we add to these the income from tax-free bonds, which practically all went to the same people, we will have, roughly speaking, a total net income of $\$ 30,000,000,000$. About $35,000,000$ other people in the United States have incomes and it is safe to figure their income at $\$ 30,000,000,000$. Then we have two groups of people each with a net income of about $\$ 30,000,000,000$ : the first group consists of the income taxpayers and their dependents, about $15,000,000$, and the second of the balance of the people, $90,000,000$. This would make the average income of the first group $\$ 2,000$, and of the second group $\$ 333$.

If we divide the budget $\$ 5,600,000$,000 by the population $105,000,000$ it makes the per capita tax $\$ 50$. The practical question now arises: How much of the total budget of $\$ 5,600$,000,000 shall be collected from these average incomes of $\$ 333$ ? My answer is, not to exceed 25 per cent which would be $\$ 12.50$ per capita.

At the close of the Civil War approximately 75 per cent of the revenues raised by taxation were raised from consumption taxes and 25 per cent from income taxes. These figures should now be reversed and approximately 75 per cent of the revenues raised from income taxes, and not to exceed 25 per cent from consumption taxes. For the fiscal year 1920, 73.6 per cent of the taxes came from income taxes and 26.4 per cent from consumption and other taxes, so that the present distribution of the tax burden is fair. We must bear in mind that one of the chief differences between income taxes and consumption taxes is that the bulk 
of the income tax is paid from income above the living wage, and the bulk of the consumption taxes are paid out of the living wage. These consumption taxes are paid largely out of the living wage by those least able to pay, and often in inverse proportion to their ability, as the larger a man's family, the greater the demand for goods and the less his ability to pay.

\section{Equitable Distribution of Wealth}

This is vital. America has always been regarded as the land of opportunity and nothing should be allowed to creep into our tax system that would place the man of small means or the small corporation at a disadvantage as compared to those of larger capital.

John Hays Hammond recently said: "The best thing that the Government can do is to keep the roads to success open, to see that no one erects barriers on them. And, most particularly, that it does not erect them itself. Most of us ask no more."

So much in general; let us now take up the propositions that have been generally considered in the agitation for a revision of the present tax system.

\section{The Personal Income Tax}

All are now familiar with the general provisions of the personal income tax. There is first the exemption of $\$ 1,000$ for a single man, $\$ 2,000$ for a man and wife and $\$ 200$ for each child and then a tax of four per cent up to $\$ 4,000$ of net income and eight per cent above $\$ 4,000$. This is called the normal tax; to this is added above $\$ 5,000$, the surtaxes, increasing one per cent to $\$ 6,000$, then increasing one per cent for each $\$ 2,000$ of net income up to $\$ 100$,000 . From $\$ 100,000$ to $\$ 150,000$ the rate is 52 per cent; from $\$ 150,000$ to $\$ 200,000,56$ per cent; from $\$ 200,000$ to $\$ 300,000,60$ per cent; from $\$ 300,000$ to $\$ 500,000,63$ per cent; from $\$ 500,000$ to $\$ 1,000,000,64$ per cent; and above $\$ 1,000,000,65$ per cent.

Incomes above $\$ 1,000,000$, therefore, pay a normal tax of eight per cent and surtaxes of 65 per cent, or 73 per cent in all. Experience seems to show that this rate is too high to produce the maximum amount of revenue and that the higher brackets should be reduced. Men of large incomes are avoiding the payment of these higher taxes by investing in tax-free bonds. The income tax returns for 1919 , the last year from which figures are available, show $5,600,000$ returns with a net income of $\$ 20,000,000,000$ and a tax of $\$ 1,350,000,000$, or 5.1 per cent.

The rates should be so changed that the maximum tax would not exceed 50 per cent of the net income. This would substantially agree with the practice of both France and England. It is preferable to reducing the tax on saved and reinvested income to a maximum of 20 per cent. One of the reasons for objecting to a maximum tax of 20 per cent on saved and reinvested income is that, if the excess profits tax were abolished and the maximum surtaxes reduced to 20 per cent, it would open a channel whereby the enormous profits of some corporations could be secured by very wealthy men at a relatively low tax rate.

\section{Excess Profits Tax}

It must be borne in mind that corporations are taxed under a different schedule than individuals. The corporation pays a normal tax of 10 per cent on net income in excess of certain credits, provided in Section 236, and the excess profits tax.

Under the excess profits tax the corporation has first an allowance of $\$ 3,000$ and eight per cent on the invested capital (Sec. 3i2), then the rate is 20 per cent up to 20 per cent on the invested capital and 40 per cent of the 
net income above that figure. This tax produced during the last fiscal year $\$ 1,750,000,000$, by far the largest single item. Owing to the unfavorable business outlook, it is estimated that it will produce this year $\$ 900,000,000$ of revenue.

There is a very strong movement on foot to repeal the excess profits tax. The chief arguments for the repeal of the tax are:

1. That it is a heavy burden on business and that it takes from the corporations money needed for dividends and additional capital.

It is admitted that it is a heavy burden, but the raising of a budget of approximately $\$ 5,600,000,000$ is bound to be a heavy burden on someone. Every dollar of the $\$ 1,750,000,000$ collected from this source last year came out of profits, and before any of it was levied, the corporations had an allowance of $\$ 3,000$ and eight per cent on their invested capital; that the rate above this allowance was 20 per cent up to 20 per cent on invested capital, and that above that 40 per cent. This would seem to allow the corporations sufficient funds for all reasonable requirements of capital and dividends. It is reasonably certain that most farmers would be glad to pay the tax if they could get into the excess profits class.

2. That the amount of invested capital can not be determined and the law is unworkable.

The answer is that the law has been in effect since $191 \%$, that whether the law is revised or not, the invested capital will have been determined for most corporations for four years and when once determined the adjustment each year is a comparatively simple matter; unless it can be shown that this tax is based on wrong principles or works injustice, the proper remedy is not its abolition, but the improvement of its administration.
3. That the amount of revenue from this source is diminishing.

This might be an argument for increasing the tax, but certainly not for its abolition so long as we need the revenue.

4. That the tax is passed on in aggravated form to the consumer and adds as much as 23 per cent to the H.C.L.

Please note that it is the corporations who pay the tax, and not the public, who are asking for its repeal: that is sufficient answer.

Another evidence that the excess profits tax is not destroying business in corporate form is the amount of capital put into new corporations of over $\$ 100,000$ capital during the last three years. Thefigures are as follows: for $1918, \$ 2,599,000,000$; for $1919, \$ 12$,$677,000,000$; for $1920, \$ 13,998,000,-$ 000 ; this does not look much as if the public had lost faith in the earning power of corporations even with the excess profits tax.

5. That it encourages extravagances as part of advertising bills, etc., which would come out of money that would otherwise go to the government.

The corporation in any case will be spending 50 per cent of its own money and is not likely to go very far strewing the country with its funds. This is one of the arguments put forward by the advertisers: furthermore, the regulations will keep these expenses within bounds.

6. That it excites hostility because the details of the corporate business have to be set forth.

This works for good in every way. In many instances the corporation itself gets a lot of valuable facts presented for its enlightenment. It will put a curb on false statements to stockholders and the public and tend to the establishment of sound and adequate methods of accounting.

As a matter of fact the advocates of 
repeal of this tax have not made out any case, and when hard pressed take refuge in No. 2 (that the law is unworkable), in face of the fact that it has been in force for four years and that the difficulties involved will grow less each year. They have not presented a single vital reason for its repeal, while there are several fundamental reasons for retaining it. The reasons for retaining the excess profits tax are:

1. We need the money. This is not questioned.

2. It is based on net income-the correct principle-and every dollar collected by this tax comes from profits after liberal allowance has been made for dividends and expansion of capital.

3. The tax is progressive and the higher rate-40 per cent-does not apply until after the corporation has 17 per cent on its invested capital.

If the excess profits tax should be repealed, it would allow corporations making large earnings running up to 200 per cent and over, to escape with paying only the normal tax, an entirely inadequate share of the tax burden; and this is one of the strongest arguments against its repeal.

If it is urged that corporations are owned by individuals who pay surtaxes, the answer is that corporations are artificial persons created by the state, and receive many advantages not enjoyed by the individual; that, in return, the state is justified in taxing them; that, in the case of the railroads, the state has said that they shall not take from the public over six per cent on their invested capital, and that it would be justified in using the excess profits tax to prevent corporations profiteering at the expense of the public. A flat tax encourages profiteering as compared with a progressive tax, because with a flat tax, what they get above the tax they keep, while with a progressive tax, the more they make, the more the government taxes; and the rates could be so arranged as to be a decided discouragement to excessive profits. It will tend to widen distribution of wealth (see Principle No. 4), from the fact that individuals with very large incomes will put their money into tax-free securities of low earning power, rather than in stock paying the excess profits tax, and then themselves pay the surtaxes. Automatically the stocks of corporations with large earning power will fall into the hands of a large number of persons of moderate income, which is just where it will do the most good. While this may not have been one of the controlling reasons for establishing the existing system, it is a very good reason for retaining it.

Another of the collateral effects of the excess profits tax is that in a measure it tends toward equalizing the net returns as between those corporations differing in natural advantages as to fuel, raw material, etc.; for example, during the war the government commandeered all the wood chemical plants in the country and fixed the price on the product the same for all factories without regard to cost of production. This allowed the large factories and those most favorably located to make the most money, but along comes the war profits tax and excess profits tax, and those with large profits have to surrender a goodly portion to the government; and thus things are, to a certain extent, evened up. Today these factories all sell on the open market at practically the same price, and the excess profits tax will help equalize things.

The repeal of this tax involves finding some other source from which an equal amount of revenue can be derived and, so far as my knowledge goes, all the remedies proposed are worse than the disease. An analysis 
of all the substitutes shows, invariably, an effort to free incomes of a large part of the burden they are now carrying, and substitute them for consumption taxes, which would be paid largely out of the living wage, and which would then fall on those least able to pay, and in many cases in inverse proportion to the man's ability, as the larger the family, the more demand for goods.

Nothing could be more short-sighted or ill-advised, from the standpoint of the corporations and of capital, than any attempt to relieve the corporations and shoulder the burden off onto the common people through consumption taxes. This would furnish a text from which to preach sermons to which there would be no answer.

\section{The Sales Tax}

The sales tax, as set forth by its friends, is purely a consumption tax. This has been proposed in three forms:

1. A general turnover tax on all business including personal services and capital assets.

2. A tax on goods, wares, and merchandise.

3. A tax on retail sales.

This proposition is fundamentally unsound in all its forms:

If it is not passed on to the ultimate consumer:

1. Because it is founded on the wrong theory (See Principle No. 1). The basis of the tax would be gross income and the tax would have to be paid whether there were any profit in the business or not. In many cases it would be paid out of capital where there is no profit from which to get it. Where there was no profit and where it would not be passed on, it would be a capital levy just as much as the German law, although disguised and under another name.

2. It would give the larger and stronger concerns enormous advantage, and eventually concentrate the business in each particular line in the hands of a few very powerful concerns. Take the shoe business for example. There is one concern that buys the hides in South America and sells the shoes to the wearer. This concern would have a tax of one per cent on the finished shoes. Take another small concern. The hides are gathered up by a dealer, sold to a tannery, sold to a jobber, to a shoe manufacturer, to a jobber, to a retailer: here the tax would be paid six times, a difference of three per cent in costs will determine who gets the business in shoes. It is readily seen that it would only be a question of time when a few large concerns would control the shoe business. The same thing is true of many other industries.

3 . The country would cease to be the land of opportunity and the door would be permanently closed to the great body of the people. This is not a new proposition; it has been tried and abandoned by many countries and today is only resorted to in dire extremity. France has a sales tax because there was no other way, short of a capital levy, to get the money and even in France the people are evading the tax in large part. In January, 1921, this tax produced only one-third the estimates.

If it is passed on to the ultimate consumer:

1. Because it would place an unfair share of the tax burden on those least able to bear it, and it is equally indefensible if not passed on, because the amount of the tax will bear no relation to the amount of profits in the business.

The trouble of administering the excess profits tax for 350,000 corporations, 100,000 of which make no profits, another 100,000 only very small profits, and only 150,000 profits enough to be a 
factor, is as nothing compared with checking the infinite number of accounts involved in sales tax schemes. It would be "out of the frying pan into the fire" with a vengeance. One of the requisites of a good tax is ability to check the returns. This could not be done adequately with the enormous number of accounts involved. Only recently a gentleman who has just come back from France stated that while there he purchased 30,000 francs' worth of merchandise, and that he did not pay any sales tax.

Consider the farmer. His gross overturn is approximately $\$ 20,000,000,000$; a tax of one per cent would be $\$ 250,000,000$. We know how much could be added to the price of our grain, or cattle, or dairy products if a gross turnover tax were paid each time the farmer's products changed hands. As much of the farmer's overturn is without profit, this tax on the farmer would have to be paid out of capital.

\section{The TarifF}

Most people can remember when agriculture received some consideration in framing our tariff laws. Both the manufacturers and labor are interested in agriculture, primarily as a supply of food and raw materials. They wanted them cheap. Practically all the duties were taken off and the farmer left to compete with cheap beans from Manchuria, cheap wool from Australia, and cheap labor the world over, while the factory demanded protection and got it.

The result was that the farmer was left to sell in a free-trade market, and buy in a protected market. He has no protection on wool, but the cloth his coat is made of has a protection of $\mathbf{3 5}$ per cent. The dairy farmers have to compete with Canadian milk and cheese, with butter from Denmark, and with condensed milk from the world. These results have been brought about largely because business and labor are organized and speak with authority, and the farmer has had no organization with sufficient weight and authority to present his side of the argument. The time has come when all genuine farmers' organizations should unite in demanding a square deal and the consideration for agriculture that is befitting the basic industry of the country. A large share of the consumption taxes can appropriately be collected through the tariff, but we should not be so carried away with the idea of a protective tariff as to allow taxes on tea, coffee and sugar, and other articles to be substituted for income taxes. If this is done, the farmer and the wage-earner will pay the bill.

There are many other minor suggestions offered that would make up part of the revenue lost by the repeal of the excess profits tax, such as to increase the normal corporation tax from ten per cent to sixteen per cent and abolish the $\$ 2,000$ exemption. This is wrong, primarily because it is a flat tax and bears hardest on those with least incomes. One of the strong points in favor of the progressive taxes is that they help to equalize the final earnings of the strong and weak, and thus prevent monopoly. Other suggestions are the following:

Increase the stamp taxes.

Increase the first-class postal rate to three cents.

Place taxes on tea, coffee, sugar and other items of wide use.

Increase the rates on tobacco, cigarettes and many other non-essentials.

(They should not be substituted for income or the excess profits tax.)

A careful study of the present tax system will be convincing to show that the framers of the present law did a 
surprisingly good job, under all the circumstances; and that while it is very easy to abolish the excess profits tax, it is exceedingly hard to find a substitute that is not worse.

I offer the following suggestions:

1. Reduce the higher surtax brackets on individuals so that the maximum tax does not exceed fifty per cent.

2. Revise the administrative features of the excess profits tax and establish local board in each district where at least 90 per cent of all the returns can be checked and passed upon, and only the most complicated sent to Washington. This will be in line with the English method, which works very well.

3. Establish a Board of Adjustment to which cases can be referred for final settlement.

4. That the Constitution be amended so that there will be no tax-free securities and all income will be taxed.

5. That 75 per cent of the taxes be raised from income taxes and 25 per cent from consumption and other taxes.

That the present income tax and excess profits tax do not produce sufficient revenue; that the rates be raised sufficiently on individual incomes between $\$ 10,000$ and $\$ 50,000$ to make up the difference.

6. The enactment of H.R. 14198 .

7. That net loss for any year may be deducted from the succeeding year or years.

\title{
The Ralston-Nolan Bill
}

\section{A Proposed Tax on Unimproved Land Values}

\author{
By S. H. Patterson \\ Instructor in Economics, University of Pennsylvania
}

"T

THE tariff a local issue" was made the presidential campaign slogan of a generation ago. The same might be said of taxation. Various individuals are vigorously agitating for the repeal of certain taxes which they find repressive - that is, which hit them. They feel that the industrial prosperity of the country will be furthered by other kinds of taxes, the final burden of which seems to lie in another direction. The political atmosphere is full of taxes and rumors of taxes.

On February 7, 1920, Mr. Nolan introduced into the House of Representatives a bill taxing large land values, which was subsequently referred to the Ways and Means Committee. The measure is technically known as House of Representatives Bill No. 12397 or more popularly as the RalstonNolan Bill. It proposes to "provide for the raising of public revenues by a tax upon the privileges of the use and enjoyment of lands of large value." The bill defines land in its true economic sense, that is, including all natural resources and excluding all improvements which represent labor and capital.

That for the purposes of this Act, land is defined to be the surface of the ground, with all easements in, on, and over the same whether covered by water or not, and including water powers and rights, natural growths, if any, of land and including wild forests, natural deposits of coal, minerals of all kinds, oils, gases, peats, waters and all other substances and not including the improvements the result in whole or in part of the application of labor to land.

The rate of taxation is one per cent upon all land values in excess of ten thousand dollars. 